\title{
Successful New Inhibitive Water-Based Fluid Application, Sulige Gas Field,China
}

\author{
Ming Zhang ${ }^{1, \text { a,* }}$,Tiantai $\mathrm{Li}^{1, \mathrm{~b}}$, Ziqiang $\mathrm{Xu}^{2, \mathrm{c}}$ and $\mathrm{Da} \mathrm{Li}^{2, \mathrm{~d}}$ \\ ${ }^{1} X i$ 'an Shiyou University, Xi'an 710065, China \\ ${ }^{2}$ Changqing Oil field Company,Xi'an, 710021,China \\ am9792@xsyu.edu.cn, ${ }^{b} t t l i @ x s y u . e d u . c n,{ }^{c} 576513231 @ q q . c o m$, \\ d2250662486@qq.com \\ *Ming Zhang
}

\begin{abstract}
This study developed a new type of shale drilling anti-collapse inhibitor and compounded a set of stable shale water-based drilling fluid for horizontal wells to effectively solve hole shrinkage, collapse, tool sticking, and other complex downhole problems involved in the shale drilling at the horizontal section of the Sulige gas field. Laboratory experimental evaluations indicated that this system had a strong inhibitory effect on shale formation and sound compatibility. After its weight reached $1.20 \mathrm{~g} / \mathrm{cm} 3$, the system exhibited a stable rheology, lubricity, filter loss, high recovery rate of rock debris, and low formation damage. The mud cake was smooth, thin, tough, and compact. The drilling fluid also maintained suitable anti-collapse capability, lubricity, rheology, and highly efficient debris-carrying and well-flushing ability in its field application in the drilling of the shale section of the Sulige gas field. The tripping operation exhibited no clear resistance and sticking. This system achieved significant effects and satisfied the requirements of the drilling construction of a horizontal well in the Sulige gas field.
\end{abstract}

Keywords: borehole instability; drilling fluid; anti-collapse inhibitor; Sulige gas field

\section{Introduction}

Borehole instability is a common problem in the downhole conditions of drilling engineering and can seriously influence the record of geological data, drilling speed, quality, and cost [1-3]. Shale makes up 75\% of drilled formations and causes $90 \%$ of wellbore instabilities [4]. Borehole instability occasionally hinders target formation, further delays the exploration and development speed, and influences the economic benefits [5-6]. In recent years, a non-soil phase and low damage temporary-blocking drilling fluid system has been adopted for the exploration of horizontal wells at the horizontal section of the Sulige gas field. This system has achieved success in its application in horizontal wells, given its low density, high acid solubility, high core recovery rate, and small formation damage. However, this system now faces new challenges given the large-scale development of continuous horizontal well extension at the horizontal section of the Sulige gas field. Given that the reservoir formation of the Sulige gas field is characterized by strong heterogeneity, the probability of obtaining shale from the drilling at the horizontal section of the field increases. The improvement of the drilling fluid density has generally been adopted to balance the formation pressure of shale drilling, but this approach can lead to high solid content and high friction of the drilling fluid. It still cannot effectively prevent shale collapses at the horizontal section, drilling sticking, tool sticking, and other accidents, which pose high risks to the construction of the horizontal section.

${ }^{*}$ Corresponding Author 


\section{Shale Formation Analysis of the Horizontal Section}

\subsection{Conditions of Shale Drilling}

According to the investigation of over 20 wells Table 1, it can be known that it is common for shale drilling at the horizontal section in Sulige gas field as well as collapses of different degrees, which causes complex downhole problems, difficult directional drilling, low penetration speed and so on.

Table 1. Statistics of Some Shale Drillings in Sulige Gas Field

\begin{tabular}{|c|c|c|c|c|}
\hline Well No. & $\mathrm{S} 5-2 \mathrm{H} 2$ & $\mathrm{~S} 2-9 \mathrm{H} 2$ & S6-4H1 & S1-6H1 \\
\hline $\begin{array}{l}\text { Length of the shale } \\
\text { section } \\
\text { (m) }\end{array}$ & $\begin{array}{c}2864.3-2946.3 \\
2977-2996 \\
3054.38- \\
3121.81 \\
3124.81-3179.9 \\
3198.97- \\
3247.14 \\
3275.89- \\
3294.12 \\
3304.77- \\
3330.63 \\
3333.59-3412\end{array}$ & $\begin{array}{c}2706.95- \\
2813.48 \\
2916.36- \\
2966.45 \\
3031.74- \\
3075.96 \\
3099.07- \\
3141.52 \\
3195.24- \\
3335.60 \\
4332-4385\end{array}$ & $\begin{array}{c}3582- \\
3600 \\
3603- \\
3939 \\
3948- \\
3978\end{array}$ & $\begin{array}{c}3130- \\
3144 \\
3270- \\
3287 \\
3416- \\
3500 \\
3520- \\
3548 \\
3950- \\
3960 \\
4013- \\
4061 \\
\end{array}$ \\
\hline $\begin{array}{l}\text { The cumulative length } \\
\text { (m) }\end{array}$ & 394.19 & 436.65 & 384 & 201 \\
\hline
\end{tabular}

\subsection{Analysis of Mineral Components}

Clay mineral of shale at the horizontal section in Sulige gas field is primarily made of illite/smectite and illite and generally contains kaolinite and chlorite, shown as Figure 1, and Table 2.
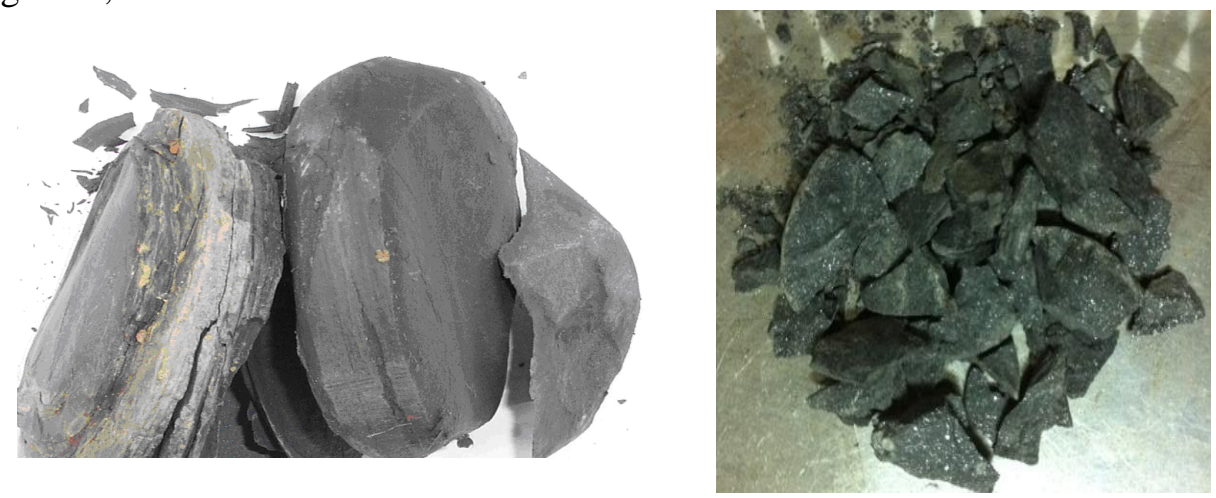

Figure 1. Shale Sample at P2sh of Sulige Gas Field

\subsection{Analysis of the Physicochemical Properties of the Formation}

$24 \mathrm{~h}$ expansion rates at $\mathrm{P}_{2}$ sh of Sulige gas field are over 15\%, with maximum of $35.2 \%$; its dispersion is poor and the recovery rate falls between $10-30 \%$, belonging to a formation with high hydration degree. P2sh is the major collapse formation of Sulige gas field and its mean cation exchange capacities respectively are 14.71 and $23.90 \mathrm{mmol} / 100 \mathrm{~g}$ 土. According to Ormghy theory, the cation exchange capacity of illite at non-expansive crystal layer is lower than $15 \mathrm{mmol} / 100 \mathrm{~g}$ 土, which indicates 
that illite/smectite in the shale at P2sh contains certain amount of expansive crystal layer.

Table 2. Major Mineral Components of the Formation in Sulige Gas Field

\begin{tabular}{ccccccccc}
\hline & & & & \multicolumn{5}{c}{ Relative mineral contents (\%) } \\
\cline { 5 - 7 } Well No. & $\mathrm{H}(\mathrm{m})$ & Formation & $\begin{array}{c}\text { Petrographic } \\
\text { description }\end{array}$ & $\begin{array}{c}\mathrm{I} / \mathrm{S} \\
\mathrm{R}>\end{array}$ & $\mathrm{I}$ & $\mathrm{K}$ & $\mathrm{C}$ & lit-par-lit ratio S\% \\
& & & & & & & \\
\hline S7-9 & 2852 & $\mathrm{P}_{2}$ sh & Sandy mudstone & 71 & 20 & 4 & 5 & 25 \\
S7-9 & 2899 & $\mathrm{P}_{2}$ sh & Sandy mudstone & 57 & 27 & 6 & 10 & 25 \\
S7-9 & 2946 & $\mathrm{P}_{2}$ sh & Sandy mudstone & 56 & 28 & 6 & 10 & 25 \\
S7-9 & 2992 & $\mathrm{P}_{2}$ sh & Sandy mudstone & 60 & 26 & 7 & 7 & 20 \\
S7-9 & 3039 & $\mathrm{P}_{2}$ sh & Sandy mudstone & 59 & 33 & 3 & 5 & 20 \\
S5 & 3115 & $\mathrm{P}_{2}$ sh & mudstone & 69 & 18 & 7 & 6 & 35 \\
S5 & 3301 & $\mathrm{P}_{2}$ sh & mudstone & 52 & 25 & 15 & 8 & 20 \\
S6-4 & 3306 & $\mathrm{P}_{2}$ sh & mudstone & 84 & 5 & 7 & 4 & 35 \\
S20 & 3345 & $\mathrm{P}_{2}$ sh & mudstone & 73 & 9 & 11 & 7 & 30 \\
S11 & 2981 & $\mathrm{P}_{2}$ sh & mudstone & 41 & 31 & 20 & 8 & 20 \\
\hline
\end{tabular}

Table 3. Physicochemical Properties at P2sh of Sulige Gas Field

\begin{tabular}{lllllllll}
\hline & & \multicolumn{3}{c}{$\begin{array}{c}\text { Expansion } \\
\text { Well H } \\
\text { No. (m) }\end{array}$}
\end{tabular}

\section{Preparation and Performance Evaluation of Stable Shale Inhibitor}

The abroad application of anti-collapse organic amine inhibitor is relatively mature while the domestic field application is few [7-8]. The inhibition mechanism of organic amine inhibitor is different from traditional inhibitory drilling fluid and by aid of unique molecular structure of organic amine, this inhibitor can well inlay between clay formations and connect the clay formations tightly [9-11]. Thus, it can decrease the moisture absorption trend of clay and have a strong inhibitory effect on the hydration of shale. Compared with cationic polymer, polymeric alcohol and silicate drilling fluids, this new organic amine not only owns strong inhibitory effect on hydrous disintegration but also has better firm formation function, which can prevent drill bit balling and improve the penetration speed [12-14].

\subsection{Synthetic Process}

Organic amine polymer is obtained from epoxide (ethylene oxide and / or propylene epoxide) and cationic monomer with catalyst. 


\subsection{Major Instruments}

(1)Polyreactor: $3 \mathrm{M}^{3}$ or larger, including nitrogen charge device, stirrer, temperature regulating device $\left(0-200{ }^{\circ} \mathrm{C}\right)$, cooling device and so on; (2) Aging reactor: $3 \mathrm{M}^{3}$ or larger; (3) raw material storage tank: $20-30 \mathrm{M}^{3}$; (4) metering pump.

\subsection{Main Raw Materials and Dosage}

(1)Ethylene oxide: $50-80 \mathrm{~kg}$; (2) propylene epoxide: $50-100 \mathrm{~kg}$; (3) organic amine: $30-55 \mathrm{~kg}$; (4) initiator: $10-15 \mathrm{~kg}$; (5) catalyst: $1-3 \mathrm{~kg}$; (6) water: $10-20 \mathrm{~kg}$.

\subsection{Technological Process}

Initiator is added in the reactor and then catalyst and organic amine are dropped in under stirring. Later, water of certain amount is added. Replace for 2-3 times by nitrogen charge. It is heated and stirred until $80^{\circ} \mathrm{C}$ and epoxide is dropped, with pressure lower than $10 \mathrm{MPa}$ and temperature lower than $180{ }^{\circ} \mathrm{C}$. In the reaction process, if the pressure is overly high, charge is stopped feeding in until temperature and pressure decrease. After the drop is over, keep the reaction for 30-40h and cool until the temperature is lower than $50{ }^{\circ} \mathrm{C}$. In this way, colorless or pale yellow viscous liquid is obtained, with trade name of organic amine inhibitor and code name of AI509.

\subsection{Performance Evaluation}

The reaction product is used as inhibitor, so this paper focused on investigating its inhibition performance and its influences on rheology and filter loss of the drilling fluid.

1) Experiment of expansibility

Experimental data in Table 4, show that the expansibility of core in AI509 test liquid is lower than that in pure water.

Table 4. Experiment Results of Expansibility

\begin{tabular}{ccccc}
\hline Reagent & Dosage $(\%)$ & $L_{t} / 8 \mathrm{~h}(\mathrm{~mm})$ & $H_{(\mathrm{mm})}$ & $V_{t} / 8 \mathrm{~h}(\%)$ \\
\hline \multirow{2}{*}{ water } & $/$ & 3.41 & 13.13 & 25.97 \\
& 0.05 & 2.46 & 11.375 & 21.63 \\
\multirow{3}{*}{ AI509 } & 0.1 & 2.57 & 12.42 & 20.69 \\
& 0.25 & 2.61 & 12.27 & 21.27 \\
& 0.5 & 2.57 & 12.17 & 21.12 \\
& 1 & 2.57 & 12.05 & 21.33 \\
\hline
\end{tabular}

2)Experiment of flocculation

Experiment of flocculation is the most intuitive evaluation means to evaluate the inhibitory effect of inhibitor on clay hydration. In the experiment, the lower the height of flocculate interface is, the more obvious the inhibitory effect of treating agent is. 


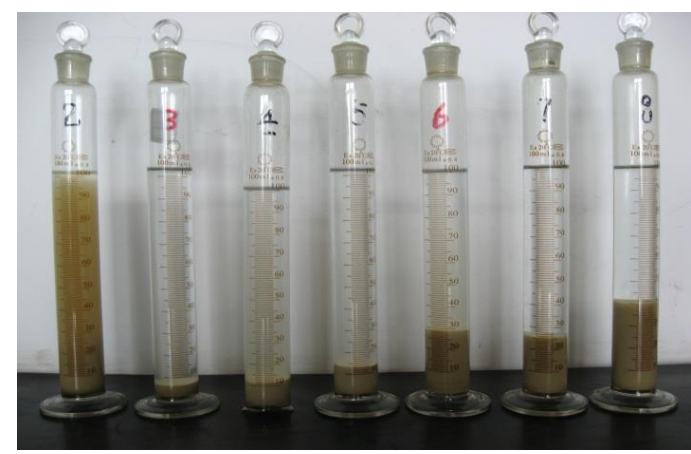

Figure 2. Experiment Results of Flocculation

\section{2\#:water;3\#:7\%KCl;4\#:1\% AI509;5\#:0.5\% AI509, 6\#:0.25\% AI509;7\#:0.1\% AI509;8\#:0.05\% AI509}

It can be seen from Figure 2, that after 24h' standing, with tiny dosage of AI509 (8\#), a strong flocculation effect is generated. With the increasing dosage, the flocculation effect gradually strengthens. When the dosage of AI509 is increased to $1 \%$, the height of flocculate is about 11 (scale reading of measuring cylinder), which is twice of that of $7 \% \mathrm{KCl}$. Thus, the flocculation effect is good.

Table 5. Experiment Results of the Influences of Al509 on Drilling Fluid Performance

\begin{tabular}{|c|c|c|c|c|c|c|}
\hline Reagent & $\begin{array}{c}\text { Dosage } \\
(\%)\end{array}$ & $\mathrm{AV}(\mathrm{mPa} \cdot \mathrm{s})$ & $\mathrm{PV}(\mathrm{mPa} \cdot \mathrm{s})$ & $\mathrm{YP}(\mathrm{Pa})$ & $\mathrm{FL}(\mathrm{ml})$ & Note \\
\hline \multirow{6}{*}{$\begin{array}{c}4 \% \\
\text { Swelling } \\
\text { soil }\end{array}$} & \multirow[t]{2}{*}{ I } & 12.5 & 5 & 7.5 & 32.8 & $\begin{array}{l}\text { at room } \\
\text { temperature }\end{array}$ \\
\hline & & 6.0 & 5 & 1.0 & 36.6 & $120^{\circ} \mathrm{C} / 16 \mathrm{~h}$ \\
\hline & \multirow[t]{2}{*}{0.05} & 13.5 & 6 & 7.5 & 24.0 & $\begin{array}{l}\text { at room } \\
\text { temperature }\end{array}$ \\
\hline & & 10.0 & 6 & 4.0 & 28.0 & $120^{\circ} \mathrm{C} / 16 \mathrm{~h}$ \\
\hline & \multirow{2}{*}{0.10} & 13.5 & 6 & 7.5 & 24.6 & $\begin{array}{l}\text { at room } \\
\text { temperature }\end{array}$ \\
\hline & & 10.5 & 6 & 4.5 & 27.4 & $120^{\circ} \mathrm{C} / 16 \mathrm{~h}$ \\
\hline \multirow{6}{*}{ AI509 } & \multirow{2}{*}{0.25} & 12.5 & 6 & 6.5 & 26.2 & $\begin{array}{l}\text { at room } \\
\text { temperature }\end{array}$ \\
\hline & & 9.5 & 6 & 3.5 & 28.0 & $120^{\circ} \mathrm{C} / 16 \mathrm{~h}$ \\
\hline & \multirow[t]{2}{*}{0.5} & 13.0 & 6 & 7.0 & 25.4 & $\begin{array}{l}\text { at room } \\
\text { temperature }\end{array}$ \\
\hline & & 10.0 & 6 & 4.0 & 28.0 & $120^{\circ} \mathrm{C} / 16 \mathrm{~h}$ \\
\hline & \multirow[t]{2}{*}{1} & 13.5 & 7 & 6.5 & 26.4 & $\begin{array}{l}\text { at room } \\
\text { temperature }\end{array}$ \\
\hline & & 9.5 & 6 & 3.5 & 29.8 & $120^{\circ} \mathrm{C} / 16 \mathrm{~h}$ \\
\hline
\end{tabular}

3) Evaluation of the influences on the drilling fluid performance

It can be seen from the experiment results in Table 5 that at room temperature the influences of AI509 on viscosity and shearing force of drilling fluid are small. After aging at $120^{\circ} \mathrm{C}$, filter loss of the drilling fluid caused by AI509 decreases slightly.

4) Comparative evaluation of inhibitory effects

Field rock debris from Sulige gas field is selected for the experiment of the recovery rate. The performances of organic amine inhibitor AI509, inorganic salt 
WJ-1, organic salt YJ-B and abroad polyamine are compared. Results are shown as Table 6.

Table 6. Comparative Experiment Results of Inhibitory Effects $\left(120^{\circ} \mathrm{C} \times 16 \mathrm{~h}\right)$

\begin{tabular}{ccccc}
\hline No. & Test solution & $\begin{array}{c}\text { Once recovery rate } \\
(\%)\end{array}$ & $\begin{array}{c}\text { Secondary recovery rate } \\
(\%)\end{array}$ & $\begin{array}{c}\text { Triple recovery rate } \\
(\%)\end{array}$ \\
\hline 1 & Water & 40.82 & 17.74 & 8.98 \\
2 & $1.5 \%$ polyether & 48.04 & 25.28 & 13.46 \\
3 & $0.5 \%$ AI509 & 96.46 & 96.26 & 95.34 \\
4 & $1.0 \%$ AI509 & 96.30 & 96.18 & 95.07 \\
5 & $0.5 \%$ & 87.60 & 83.58 & 83.40 \\
& polyamine & & & \\
6 & $1.0 \%$ & 90.62 & 88.78 & 86.10 \\
7 & polyamine & & 18.76 & 11.10 \\
8 & $7 \% \mathrm{NaCl}$ & 36.06 & 34.16 & 21.86 \\
9 & $7 \% \mathrm{YJ}-\mathrm{B}$ & 64.52 & 41.26 & 31.12 \\
\hline
\end{tabular}

It can be seen from the experiment results in Table 6 that with tiny dosage of AI509 $(0.5 \%)$, the inhibitory effect is good and the recovery rate of rock debris is obviously higher than that of the abroad polyamine products, with over $93 \%$ once, secondary and triple recovery rates. Moreover, the secondary and triple recovery rates are far higher than those of other products.

It can be seen from the comprehensive analysis of the above experimental data, organic amine inhibitor AI509 owns good inhibitory effect on shale hydration swelling and at the same time with good compatibility with the drilling fluid, it is an excellent inhibitor to prepare the water-based drilling completion fluid with strong inhibition and high performance. It is suitable for the shale drilling requirements of the horizontal section in Sulige gas field.

\section{The Formulation of Drilling Fluid System}

\subsection{Experiment of Compatibility}

Organic amine inhibitor AI509 is a polymer of cation and non-ion. However, cationic polymer usually has compatibility problems with most common anionic treatment agents. Thus, the experiment of compatibility is necessary to carry out and results are shown as Table 7.

Table 7. Experiment Results of Compatibility

\begin{tabular}{ccc}
\hline Formulation & $\mathrm{AV}(\mathrm{mPa} \cdot \mathrm{s})$ & $\mathrm{PV}(\mathrm{mPa} \cdot \mathrm{s})$ \\
\hline 0.3\%PAC-H & 10.0 & 3.5 \\
0.3\%PAC-H+1.5\% AI509 & 10.0 & 6.0 \\
0.3\% G310-DQT & 5.0 & 4.5 \\
$0.3 \%$ G310-DQT +1.5\% AI509 & 6.0 & 4.2 \\
0.3\%PAM & 4.0 & 0.5 \\
0.3\% PAM +1.5\% AI509 & 3.5 & 0.7 \\
0.3\% KPAM & 2.5 & 1.0 \\
$0.3 \%$ KPAM +1.5\% AI509 & 2.5 & 1.0 \\
\hline
\end{tabular}


It can be seen that after the addition of AI509, rheology of the solution basically remains unchanged and the solubility is good, without caking, flocculation and precipitation. It shows good compatibility.

\subsection{Experiment of Compound and Dosage}

Compounding coat agent with organic amine inhibitor can improve the overall inhibition of the drilling fluid system. KPAM is selected as coat agent and the experiment data are shown as Table 8 .

Table 8. Experiment Results of Compound and Dosage

\begin{tabular}{|c|c|c|c|c|c|c|c|}
\hline \multirow{2}{*}{\multicolumn{2}{|c|}{ Formulation }} & \multirow{2}{*}{$\begin{array}{c}\mathrm{AV} \\
(\mathrm{mPa} \cdot \mathrm{s})\end{array}$} & \multirow{2}{*}{$\begin{array}{c}\mathrm{PV} \\
(\mathrm{mPa} \cdot \mathrm{s})\end{array}$} & \multirow{2}{*}{$\begin{array}{l}\mathrm{YP} \\
(\mathrm{Pa})\end{array}$} & \multicolumn{3}{|c|}{ recovery rate $(\%)$} \\
\hline & & & & & Once & Secondary & Clear water \\
\hline $\begin{array}{c}\text { water+ } \\
0.5 \%\end{array}$ & $\begin{array}{l}\text { Before hot } \\
\text { rolling }\end{array}$ & 4.0 & 3.0 & 1.0 & \multirow[b]{2}{*}{75.52} & \multirow[b]{2}{*}{69.60} & \multirow{10}{*}{$\begin{array}{l}18.06 / \\
17.08\end{array}$} \\
\hline $\begin{array}{c}\text { AI509+ } \\
0.3 \% \text { KPAM }\end{array}$ & After hot rolling & 2.5 & 2.0 & 0.5 & & & \\
\hline $\begin{array}{c}\text { water }+ \\
1.5 \%\end{array}$ & $\begin{array}{l}\text { Before hot } \\
\text { rolling }\end{array}$ & 4.2 & 2.5 & 1.7 & \multirow{2}{*}{81.36} & \multirow{2}{*}{78.60} & \\
\hline $\begin{array}{c}\text { AI509+ } \\
0.3 \% \text { KPAM }\end{array}$ & After hot rolling & 2.5 & 2.0 & 0.5 & & & \\
\hline $\begin{array}{c}\text { water + } \\
2 \% \text { AI509+ }\end{array}$ & $\begin{array}{l}\text { Before hot } \\
\text { rolling }\end{array}$ & 3.0 & 2.0 & 1.0 & \multirow[t]{2}{*}{80.86} & \multirow[t]{2}{*}{78.80} & \\
\hline $0.3 \% \mathrm{KPAM}$ & After hot rolling & 3.0 & 2.0 & 1.0 & & & \\
\hline $\begin{array}{c}\text { water }+ \\
2.5 \% \text { AI509 }\end{array}$ & $\begin{array}{l}\text { Before hot } \\
\text { rolling }\end{array}$ & 2.7 & 2.5 & 0.2 & \multirow{2}{*}{81.50} & \multirow{2}{*}{77.62} & \\
\hline$\stackrel{+}{+} \underset{0.3 \% \mathrm{KPAM}}{ }$ & After hot rolling & 3.0 & 2.0 & 1.0 & & & \\
\hline $\begin{array}{c}\text { water }+ \\
3 \% \text { AI509+ }\end{array}$ & $\begin{array}{l}\text { Before hot } \\
\text { rolling }\end{array}$ & 2.7 & 2.0 & 0.7 & \multirow[t]{2}{*}{82.80} & \multirow[t]{2}{*}{77.34} & \\
\hline $0.3 \% \mathrm{KPAM}$ & After hot rolling & 3.0 & 2.0 & 1.0 & & & \\
\hline
\end{tabular}

Note: The condition of once recovery rate is $120{ }^{\circ} \mathrm{C} * 16 \mathrm{~h}$ and the condition of secondary recovery rate $120^{\circ} \mathrm{C} * 4 \mathrm{~h}$.

It can be seen from the results when AI509 is added to $1.5 \%$, the recovery rate of rock debris is improved very slightly. Thus, it can be determined that AI509 shall fall between $1 \sim 1.5 \%$ and can be feasibly adjusted according to the actual field conditions.

\subsection{Optimization of Water Loss Agent}

G1-JLS and G3-SJS water loss agents are selected for the experiment. When the samples are prepared, the water loss is measured after sufficient hydration. Then hot rolling is kept for $16 \mathrm{~h}$ at $120^{\circ} \mathrm{C}$. To better simulate the filed working conditions, $50 \mathrm{~g}$ rock debris is added in the process of hot rolling. The experiment results are shown as Table 9.

It can be seen that when $3 \%$ G3-SJS and $1 \%$ G1-JLS are added in the system, HTHP water loss at $120^{\circ} \mathrm{C}$ is controlled within $15 \mathrm{ml} / 30 \mathrm{~min}$. Mud cake is smooth and tough, satisfying the requirement.

4)Basic formulation

Through the above experiments, the basic formulation of the drilling fluid system is preliminarily determined as

1.0-1.5\% AI509+0.2-0.3\%KPAM+0.2-0.3\%G310-DQT+1\%G1-JLS+3\%G3-SJS and it can be feasibility applied according to the field requirements. 
Table 9. Experiment Results of Water Loss

\begin{tabular}{|c|c|c|c|c|c|c|c|}
\hline No. & Experiment formulations & $\begin{array}{c}\mathrm{P} \\
\left(\mathrm{g} / \mathrm{cm}^{3}\right)\end{array}$ & $\begin{array}{c}\mathrm{FL} \\
(\mathrm{mL})\end{array}$ & $\begin{array}{l}\mathrm{FL}_{\text {HTHP }} \\
(\mathrm{mL})\end{array}$ & $\mathrm{pH}$ & $\begin{array}{c}\mathrm{PV} \\
(\mathrm{mPa} \cdot \mathrm{s})\end{array}$ & $\begin{array}{l}\mathrm{YP} \\
(\mathrm{pa})\end{array}$ \\
\hline \multirow[t]{2}{*}{1} & $\begin{array}{c}1.5 \% \text { AI509+0.3\% KPAM +0.3\%G310- } \\
\text { DQT +3\%G1-JLS+1\%G3-SJS }\end{array}$ & 1.06 & 5.6 & 18.0 & 11 & 39.0 & 13.5 \\
\hline & $120^{\circ} \mathrm{C} \times 16 \mathrm{~h}$ After hot rolling & 1.05 & 4.2 & 19.0 & 11 & 26.0 & 11.5 \\
\hline \multirow[t]{2}{*}{2} & $\begin{array}{c}1.5 \% \text { AI509+0.3\% KPAM +0.3\%G310- } \\
\text { DQT + } 2 \% \text { G1-JLS+2\% G3-SJS }\end{array}$ & 1.07 & 5.4 & 16.0 & 11 & 39.0 & 14.0 \\
\hline & $120^{\circ} \mathrm{C} \times 16 \mathrm{~h}$ After hot rolling & 1.07 & 4.6 & 16.0 & 11 & 25.0 & 6.0 \\
\hline \multirow[t]{2}{*}{3} & $\begin{array}{c}1.5 \% \text { AI509+0.3\%KPAM +0.3\%G310- } \\
\text { DQT +1\%G1-JLS+3\%G3-SJS }\end{array}$ & 1.10 & 5.2 & 12.0 & 12 & 41.0 & 15.5 \\
\hline & $120^{\circ} \mathrm{C} \times 16 \mathrm{~h}$ After hot rolling & 1.10 & 4.4 & 15.0 & 11 & 34.0 & 15.0 \\
\hline
\end{tabular}

\section{Application Examples}

1)Example 1

$\mathrm{S} 2-30 \mathrm{H} 2$ well was located in the Yishan slope of the Ordos Basin. The target gas reservoir was P2sh section. Its designed well depth was 4,256 m and length of the horizontal section was $1,000 \mathrm{~m}$, but the actual tall depth was $4,730 \mathrm{~m}$ and length of the horizontal section was $1,436 \mathrm{~m}$. There were 4 sections of mud rock at the horizontal section, with total length of $318 \mathrm{~m}$. The performance parameters of the drilling fluid in horizontal section are shown as Table 10.In the process of drilling, tripping operation was made twice and the side wall at the mud rock section was stable. The tripping operation was smooth.

Table 10 .The Parameters of the Drilling Fluid in Horizontal Section in S2$30 \mathrm{H} 2$ Well

\begin{tabular}{ccccccc}
\hline $\mathrm{H}(\mathrm{m})$ & $\rho\left(\mathrm{g} / \mathrm{cm}^{3}\right)$ & $\mathrm{pH}$ & $\mathrm{FL}(\mathrm{ml})$ & $\mathrm{AV}(\mathrm{mPa} \cdot \mathrm{s})$ & $\mathrm{PV}(\mathrm{mPa} \cdot \mathrm{s})$ & $\mathrm{YP}(\mathrm{Pa})$ \\
\hline 3330 & 1.16 & 8 & 4.0 & 30.5 & 18.5 & 12.0 \\
3431 & 1.18 & 8 & 3.8 & 37.0 & 22.5 & 15.0 \\
3590 & 1.20 & 9 & 3.6 & 35.0 & 22.0 & 13.0 \\
3662 & 1.20 & 9 & 3.5 & 37.5 & 23.0 & 14.5 \\
3734 & 1.21 & 9 & 3.6 & 34.5 & 21.5 & 13.5 \\
3880 & 1.19 & 9 & 3.0 & 36.0 & 29.0 & 17.0 \\
3956 & 1.21 & 9 & 2.0 & 46.5 & 30.5 & 16.0 \\
4085 & 1.25 & 9 & 2.0 & 50.0 & 32.0 & 18.0 \\
4127 & 1.25 & 9 & 2.0 & 53.0 & 34.0 & 19.0 \\
4250 & 1.25 & 9 & 2.0 & 56.0 & 34.0 & 22.0 \\
4475 & 1.25 & 9 & 2.0 & 47.0 & 27.5 & 14.0 \\
4550 & 1.25 & 9 & 2.0 & 46.5 & 25.5 & 13.5 \\
4640 & 1.25 & 9 & 2.2 & 50.0 & 32.0 & 18.0 \\
4730 & 1.25 & 9 & 2.0 & 58.5 & 45.0 & 23.5 \\
\hline
\end{tabular}

2)Example 2

S3-64H2 well was located in the Yishan slope of the Ordos Basin. The target gas reservoir was P2sh section. Its designed well depth was $4,604 \mathrm{~m}$ and length of the horizontal section was $1,500 \mathrm{~m}$, but the actual tall depth was $4,700 \mathrm{~m}$ and length of the horizontal section was $1,545.20 \mathrm{~m}$. There were 7 sections of mud-sandstone 
interbedding at the horizontal section, with total length of $278.46 \mathrm{~m}$. The performance parameters of the drilling fluid in horizontal section are shown as Table11.The side wall at the mud-sandstone interbedding section was stable and the tripping operation was smooth. 6 times of wiper trips were normal and $10 \Phi 146^{*} 1.6$ $\mathrm{m}$ packers were smoothly tripped in the horizontal section.

Table 11. The Parameters of the Drilling Fluid in Horizontal Section in S364H2 Well

\begin{tabular}{ccccccc}
\hline $\mathrm{H}(\mathrm{m})$ & $\rho\left(\mathrm{g} / \mathrm{cm}^{3}\right)$ & $\mathrm{pH}$ & $\mathrm{FL}(\mathrm{ml})$ & $\mathrm{AV}(\mathrm{mPa} \cdot \mathrm{s})$ & $\mathrm{PV}(\mathrm{mPa} \cdot \mathrm{s})$ & $\mathrm{YP}(\mathrm{Pa})$ \\
\hline 3161 & 1.20 & 9 & 3.0 & 49.0 & 31.0 & 18.0 \\
3269 & 1.21 & 9 & 3.4 & 45.5 & 30.5 & 15.5 \\
3374 & 1.20 & 9 & 3.2 & 51.0 & 31.0 & 17.0 \\
3457 & 1.20 & 9 & 3.2 & 48.5 & 32.0 & 16.5 \\
3556 & 1.20 & 9 & 3.2 & 47.5 & 32.0 & 15.5 \\
3661 & 1.20 & 9 & 3.2 & 48.0 & 32.0 & 16.0 \\
3757 & 1.21 & 9 & 3.2 & 51.0 & 34.0 & 17.0 \\
3912 & 1.21 & 9 & 3.2 & 52.5 & 34.0 & 18.5 \\
4035 & 1.22 & 9 & 3.2 & 57.0 & 37.0 & 20.0 \\
4183 & 1.21 & 9 & 3.2 & 47.0 & 32.0 & 15.0 \\
4333 & 1.20 & 9 & 3.8 & 57.5 & 37.0 & 20.5 \\
4486 & 1.21 & 9 & 4.0 & 59.0 & 41.0 & 18.0 \\
4608 & 1.21 & 9 & 4.0 & 60.5 & 41.0 & 19.5 \\
4700 & 1.21 & 9 & 3.0 & 59.0 & 38.0 & 23.0 \\
\hline
\end{tabular}

\section{Analysis on the Field Experiment Effects}

1) High inhibitory effect and obvious anti-collapse effect of drilling fluid

Organic amine drilling fluid from the field experiment was tested, with once recovery rate of $91.6 \%$, secondary recovery rate of $90.4 \%$ and triple recovery rate of $89.8 \%$. It inhibitory effect was high. In the field experiment at the horizontal shale section of Sulige gas field 6 wells, this drilling fluid system had no chipping, collapses or hole shrinkage. Reversing-out rock debris at the mud rock section had clear and obvious edge angles Figure 3. The borehole was unblocked and the borehole diameter was regular. The cased-hole completion operation was smooth and anti-collapse effect was good.

2)Obvious lubrication and drag reduction effects of the system

The coefficients of friction resistance of the sliding block in the field drilling fluid system were below 0.07 , with torque of less than $9 \mathrm{KN} \cdot \mathrm{m}$ and tripping friction drag of less than $12 \mathrm{~T}$. The tripping process was free from resistance or blocking, which guaranteed the safe and quick drilling at the long horizontal section.

3)Small formation damage

Two cores in the experiment wells were selected and the effects of reservoir temperature and pressure on the drilling fluid system were simulated in the laboratory and evaluations were made. The experiment results are shown as Table 12. 


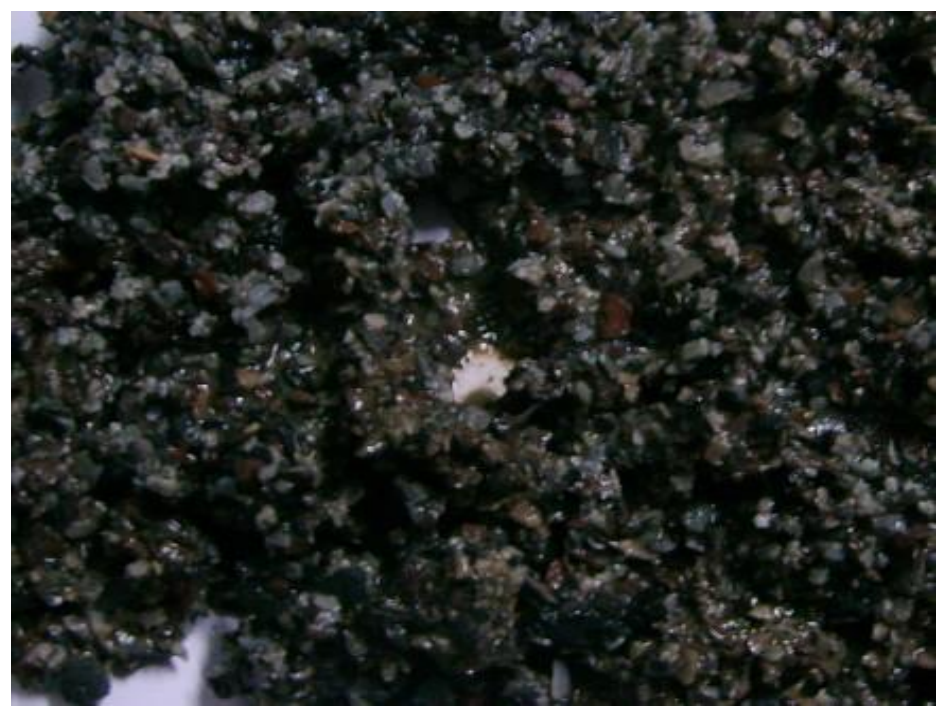

Figure 3. Reversing-Out Shale Drilling Cuttings at the Wellhead

Table 12. Experiment Results of Field Formation Damage

\begin{tabular}{ccccccc}
\hline $\begin{array}{c}\text { Well } \\
\text { No. }\end{array}$ & $\begin{array}{c}\text { Core } \\
\text { No. }\end{array}$ & Formation & $\begin{array}{c}\mathrm{Kg}_{1} \\
\left(10^{-3} \mu \mathrm{m}^{2}\right)\end{array}$ & $\begin{array}{c}\mathrm{Kg}_{2} \\
\left(10^{-}\right. \\
\left.{ }^{2} \mathrm{~m}^{2}\right)\end{array}$ & $\begin{array}{c}\text { Damage } \\
\text { rate } \\
(\%)\end{array}$ & $\begin{array}{c}\text { Mean } \\
\text { damage } \\
\text { rate } \\
(\%)\end{array}$ \\
\hline S3-1 & $216 \#$ & $\mathrm{P}_{2} \mathrm{sh}$ & 0.5098 & 0.4394 & 13.8 & \\
S3-1 & $217 \#$ & $\mathrm{P}_{2} \mathrm{sh}$ & 0.4668 & 0.3972 & 14.9 & \\
S2-18 & $139 \#$ & $\mathrm{P}_{2} \mathrm{sh}$ & 0.5245 & 0.4512 & 14.0 & 14.4 \\
S2-18 & $140 \#$ & $\mathrm{P}_{2} \mathrm{sh}$ & 0.5384 & 0.4556 & 14.8 & \\
\hline
\end{tabular}

Note: Differential pressure is $32.5 \mathrm{Mpa}$; time is $48 \mathrm{hr}$; and $\mathrm{Kg} 1$ and $\mathrm{Kg} 2$ respectively represent the permeability before and after damage

Under the simulated downhole conditions, the formation damage rates of the drilling fluid system were only $13.8 \%$ and $14.9 \%$, belonging to light damage.

4)Improved drilling rate and complete and smooth tripping in of completion tools

Drilling rate was greatly improved. The footage of single drill bit and single screw at the horizontal section of $\mathrm{S} 2-30 \mathrm{H} 2$ well was $722 \mathrm{~m}$, with mean penetration speed of $10.5 \mathrm{~m} / \mathrm{h}$, which was the currently fastest penetration speed in this region (Table 13). In case of massive mud rock, superior comprehensive performance of the drilling fluid guaranteed the safe drilling of long the horizontal section and the smooth tripping-in of cased-hole completion. Near 1, 436-1, $545.24 \mathrm{~m}$, cased hole completion with open hole packer was safely tripped at the preset position of the horizontal section, which laid foundation for further carrying out staged fracturing and increasing yield and efficiency. 
Table 13. Drilling Rate of the Test Wells

\begin{tabular}{lcccc}
\hline Well No. & $\begin{array}{c}\text { Length of the horizontal section } \\
(\mathrm{m})\end{array}$ & $\begin{array}{c}\text { Length of the shale } \\
(\mathrm{m})\end{array}$ & $\begin{array}{c}\text { ROP } \\
(\mathrm{m} / \mathrm{h})\end{array}$ & $\begin{array}{c}\text { Completion } \\
\text { method }\end{array}$ \\
\hline S5-56H1 & 905.0 & 58.0 & 9.6 & casing pipe \\
S9-56H1 & 777.0 & 181.0 & 10.0 & open hole \\
S3-64H2 & 1545.2 & 278.0 & 9.4 & open hole \\
S5-65H2 & 1000.0 & 56.0 & 8.2 & open hole \\
S2-30H2 & 1436.0 & 318.0 & 10.5 & open hole \\
S2-38H1 & 1000.3 & 339.0 & 6.9 & casing pipe \\
\hline
\end{tabular}

\section{Summary}

1) It is common to meet shale in the horizontal section of Sulige gas field. Due to collapse, tool sticking and other complex downhole problems, the directional drilling is difficult and the drilling rate is low.

2) Clay mineral of shale at the horizontal section in Sulige gas field was primarily made of illite/smectite and illite. It belonged to the formation with high hydration degree and was the major collapse formation.

3) This paper developed Organic amine anti-collapse inhibitor AI509, which owned good water solubility, strong inhibitory effect and good compatibility.

4) The prepared anti-collapse drilling fluid system of the horizontal wells owned strong inhibitory effect on shale, high shale recovery ratio, $120{ }^{\circ} \mathrm{C}$ temperaturetolerance as well as good rheology.

5) In the Sulige gas field 6 wells, this system manifested good stabilizing capacity of borehole, high purifying capacity of borehole, free of downhole collapse, chipping, sand setting, low formation damage degree and high drilling rate, which solved the prominent problems at the horizontal section. It can satisfy the safe drilling of horizontal wells at the reservoir formation in Sulige gas field.

\section{Acknowledgement}

This work was supported by the Joint Funds of the National Natural Science Foundation of China (U1262201).

\section{References}

[1] G. Chilingarian and A. Vorabutr, "Drilling and Drilling Fluids", Updated Textbook Ed.Elsevier Science Publishing Company, Inc., New York City, (1983).

[2] D. Gazaniol, F. Thierry, M. J. F. Boisson and J. M. Piau, "Wellbore failure mechanisms in shales: prediction and prevention", Journal of Petroleum Technology, vol. 47, no. 7, (1995), pp. 589-595.

[3] C. P. Tan, B. G. Richards and S. S. Rahman, "Managing physico-chemical wellbore instability in shales with the chemical potential mech-anism", SPE Asia Pacific Oil and Gas Conference, October, Adelaide, Australia, (1996), pp. 28-31.

[4] Z. Hanyi, Q. Zhengsong, H. Weian, C. Jie, H. Daquan and L. Haibin, "Successful Application of Unique Polyamine High Performance Water-Based Drilling Fluid in Bohai Bay Shale Formations", IPTC 16721, 2013 International Petroleum Technology Conferenceh, Beijing, China, (2013) March 26-28.

[5] A. Arbizu, P. Reid and H. Santos, "Field Results of Ultra-low Invasion Drilling Fluids Demonstrate Reduced Wellbore Instability, Reduced Mud Losses", Wellbore Strengthening and 
Improved Well Productivity. AADE 2006 Fluids Conference,Houston, USA, (2006) April 1112 .

[6] K. S. Hansen, G. Wang, O. Adeleye, K. V. McNeil, B. A. C. Schultz and K. Azbel, "Integrated Pre-Drill Pore Pressure and Borehole Stability Prediction for Prelude Development", OTC24221, 2013 Offshore Technology Conference, Houston, US., (2013) May 6-9.

[7] E. Stamatakis, C. J. Thaemlitz, G. Coffin and W. Reid, "A New Generation of Shale Inhibitors for Water-Based Muds", SPE/IADC Drilling Conference, Amsterdam, Netherlands, vol. 28, (1995) Feb-2 Mar.

[8] A. Patel, E. Stamatakis, J. E. Friedheim and E. Davis, "Highly inhibitive water-based fluid system provides superior chemical stabilization of reactive shale formations", AADE 2001 National Drilling Conference, , Houston, USA, (2001) March 27-29.

[9] P. Watson, B. Meize, C. Aldea and B. Blackwell, "Eastern gulf of Mexico: inhibitive waterbased drilling fluid sets ultra-deepwater records", IADC/SPE Drilling Conference, Houston, USA, (2004) March2-4.

[10] J. Estep, J. Elliott, R. Cervantes and B. Sills, "New inhibitive water-based fluid provided drilling performance comparable to invert emulsion systems in reactive shale sections", AADE National Technical Conference and Exhibition, Houston, USA, (2005) April 5-7.

[11] A. Patel, E. Stamatakis, S. Young and J. Friedheim, "Advances in inhibitive water-based drilling fluids-can they replace oil-based muds?", 2007 SPE International Symposium on Oilfield Chemistry, Houston, USA, (2007) Feburary 28-March 2.

[12] N. G. Doonechaly, K. Tahmasbi and E. Davani, "Development of high-performance water-based mud formulation based on amine derivatives", 2009 SPE International Symposium on Oilfield Chmeistry, Woodlands, USA, (2009) April 20-22.

[13] A. Patel, "Design and Development of Quaternary Amine Compounds: Shale Inhibition with Improved Environmental Profile", 2009 SPE International Symposium on Oilfield Chmeistry, , Woodlands, USA, (2009) April 20-22.

[14] M. Mehtar, M. Brangetto, A. A. Soliman, S. Mielke, N. Alfonzo and S. Young, "Effective implementation of high performance water based fluid provides superior shale stability offshore Abu Dhabi”, Abu Dhabi International Petroleum Exhibition\& Conference, Abu Dhabi, UAE,(2010), November 1-4.

\section{Authors}

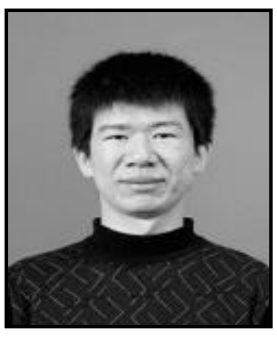

Ming Zhang, born in June 1982 in ShanDong province, China, a lecturer working in Xi' an Shiyou University; Ph.D, is engaged in researches on theories \& technologies in well drilling, reservoir protection technique during drilling and well completion.

Integrated Pre-Drill Pore Pressure and Borehole Stability Prediction for Prelude Development. OTC24221, 2013 Offshore Technology Conference 